\title{
The interrelationship between media reports and the recession in Croatia
}

\author{
Mirjana Čižmešija \\ Faculty of Economics and Business, University of Zagreb, Zagreb, Croatia, \\ mcizmesija@efzg.hr \\ Petar Sorić \\ Faculty of Economics and Business, University of Zagreb, Zagreb, Croatia, \\ psoric@efzg.hr \\ Ivana Lolić \\ Faculty of Economics and Business, University of Zagreb, Zagreb, Croatia, \\ ilolic@efzg.hr
}

\begin{abstract}
This paper builds upon the Economist's R-word (recession) index by forming a Croatian version of a media news-based economic uncertainty measure. Using the web archives of the four major Croatian news portals (Index.hr, Jutarnji list, Večernji list and 24 sata), an extensive database of as much as 531107 news articles is formed. The R-word index is obtained by calculating the monthly share of recessionrelated articles. This way Croatia is placed among the few rare world countries which have their own version of this index. It is found that the index is a leading indicator of economic activity in Croatia, preceding GDP growth rates by two months. Using rolling window correlations, the authors also prove that economic agents react to uncertainty shocks in the most intensive manner precisely at the onset of an economic crisis, while the correlation decreases in periods of more stable economic growth rates.
\end{abstract}

Keywords: Business and Consumer Surveys, economic uncertainty, leading indicator, R-word index, recession.

JEL classification: C22, C83, E03

DOI: $10.1515 /$ crebss-2017-0002

Received: December 02, 2016

Accepted: June 26, 2017

Acknowledgments: This work has been fully supported by the Croatian Science Foundation under the project No. IP-2013-3858.

\section{Introduction}

The concept of economic uncertainty dates back to Knight (1921), who separated it from the umbrella term risk (a situation in which agents can properly asses the probabilities of future events). The so-called Knightian uncertainty paradigm refers to 
unmeasurable insecurity in which decision-makers cannot evaluate the probability distributions of future outcomes. Since the phenomenon itself has been considered unmeasurable, the literature has treated it sporadically and strictly descriptively for a long period of time. However, since the Great Recession of 2008, the focus of both policyholders and the academics has shifted towards uncertainty again. E.g., Bernanke (2012) stated that "uncertainties about the situation in Europe and especially about the prospects for federal fiscal policy seem to be weighing on the spending decisions of households and businesses as well as on financial conditions. Such uncertainties will only be increased by discord and delay." Kose and Terrones (2012) similarly notice that recessions characterized by high uncertainty are longer and more intense, while recoveries followed by accentuated uncertainty are weaker.

Empirical work on economic uncertainty has also proliferated, yielding several valuable quantitative indicators of uncertainty. The Economist (2002) has published one of the earliest versions of an economic uncertainty index: the R-word (recession) index. It based its assessments on media articles reporting on contractionary economic trends. The rationale behind the index is quite straightforward: the higher the media coverage, the higher the actual uncertainty level of the economy. Several other authors also followed that route and employed media coverage as an indicator of overall uncertainty. Some of the examples include Doms and Morin (2004), Iselin and Siliverstovs (2013) or the famous Baker, Bloom and Davis (2016) economic policy uncertainty index.

It is no surprise that the researchers focused specifically on the media as the source of uncertainty. The momentous impact of media on the behaviour of individuals is well established in the literature. The media influences the overall level of individual's happiness (Cuñado, Pérez de Gracia, 2012), it has an impact on their voting preferences (Shah et al., 1999), as well as it affects their economic decisionmaking (Mullainathan and Shleifer, 2005). Precisely the latter aspect is in the focus here.

This paper bridges the gap between media content and actual economic tendencies in Croatia. In that context, the research is founded on Carroll's (2001) epidemiological model, assigning the media the central role in delivering macroeconomic information to economic agents. Carroll puts forward a hypothesis that (in accordance with the epidemiological models from the field of biomedicine), the media play a role of "disease carrier", i.e. the intermediator of information such as unemployment or inflation. Processing such information, economic agents generate their perceptions and expectations, which then determine actual macroeconomic results on the basis of a self-fulfilling prophecy principle. A similar concept is also elaborated by Raynard et al. (2008), who build a holistic theoretical model of the inflation generating process on the basis of information transfers through (inter alia) the media and word of mouth.

The main applicative goal of this study is to form and publish the Croatian version of the R-word index. The specific hypotheses (in accordance with the predominant conclusions of related international studies) are:

$\mathrm{H1}$ : The R-word index can be used as a short-term leading indicator of Croatian GDP.

An economic variable is a leading indicator if its observations up to period $t-h$ help to obtain a better estimate of real GDP at time $t$. The leading indicator is then said to have a lead time of $h$. 
$\mathrm{H} 2$ : The relationship between economic uncertainty (measured by the R-word index) and the Croatians' economic confidence is the strongest in recessionary episodes.

The second hypothesis will be tested for five distinct sectors of Croatian economy (consumers, industry, construction, retail trade, and the services sector) using data gathered through Business and Consumer Surveys (BCS).

The paper is organised as follows. The next section titled Literature review presents a critical review of related empirical studies. The section Research methodology and data presents the examined dataset, as well as the methodology of collecting and analysing media articles data, while the empirical results are presented in the next section. The last section provides the concluding remarks and policy implications, together with the recommendations for future research.

\section{Literature review}

This section explains the theoretical foundations for modelling the relationship between uncertainty and economic activity, as well as it presents the major empirical verifications of the postulated relationship.

\section{Theoretical background of the relationship between uncertainty and economic activity}

A sudden stop episode (such as the one in the Great Recession of 2008) leads to an abrupt eruption of uncertainty in the system. Kindleberger and Aliber (2011) hypothesize that such developments tend to accentuate the importance of psychological factors, which can to a large extent determine the duration and intensity of the recession.

In times of high uncertainty, economic agents tend to be risk averse (see Rabin and Thaler (2001) for an introduction of the risk aversion concept), which prevents investments, weakens entrepreneurial incentives, and discourages the overall economic growth.

The overall effect of uncertainty on both economic sentiment (confidence) and economic activity is quite clearly negative. The transmission channels, however, are not so clear. The literature identifies two main channels of influence, both of which refer to the consumer sector.

The first one is the wait and see strategy. Eberly (1994) finds that higher revenue uncertainty compels the consumers to postpone their car purchases. The mechanism itself is easily translated to the consumption of any other durable or nonessential good. This claim is ultimately confirmed by Bertola, Guiso and Pistaferri (2005). Applying a probit model for Italian consumers, they prove that income uncertainty lowers the probability of pilling the stock of durable goods.

The second channel is founded on the well-known precautionary savings motives (Carroll, 1992). He postulated that consumer protect themselves from future income uncertainty by instantly lowering their household consumption. A general outcome of this type of behaviour should be a GDP decline. However, the mechanism itself is of strictly short-term nature. Arčabić (2015) provides an empirical description of this mechanism for Croatia, proving its short-term characteristics. He found that both consumers and firms react to uncertainty shocks by lowering their investments and indebtedness. However, this kind of behaviour is only transitory, lasting up to six months. 
A possible third transmission channel (related to the financial sector) is found by Fernández-Villaverde et al. (2011). They find that agents in emerging markets (such as e.g. Croatia) protect themselves from rising uncertainty by transferring their capital to foreign markets.

The most prominent examples of media-based economic uncertainty indices are presented in the next subsection.

\section{Empirical attempts of forming a media-based economic uncertainty index}

Considering the prevailing turbulent economic conditions, several uncertainty indices have emerged lately, all of which are at least to some extent based on the media coverage on relevant economic issues. The R-word index, formed by the highly appreciated magazine The Economist (2002), is among the most influential ones. This quarterly index counts news articles from Washington Post and New York Times which include the word recession.

Doms and Morin (2004) form several alternative versions of the same index for the USA, augmenting the examined database to as much as 30 newspapers. Using various regression specifications and vector autoregression models, the authors conclude that uncertainty shocks (measured by the number of recession news articles) have a significant, but only short-term effect on consumers' economic sentiment (quantified through the renowned Michigan consumer survey).

Building upon the Economist's approach, some other countries have also introduced the R-word index for their national economies. HypoVereinsbank (2001) has published a German version of the index, which has later on been further analysed in a few studies. Bandholz and Funke (2003) dismiss the German R-word index as a reliable leading indicator, since it does not provide timely information on the German recession in 1992/1993. Grossarth-Maticek and Mayr (2008), however, tell a quite different story. Using a probit model, they prove that the R-word index correctly dates German recession episodes.

Iselin and Siliverstovs (2013) quantify a Swiss version of the R-word index, and empirically validate its predictive characteristics with respect to GDP growth. The most striking results of their study is that the forecasting accuracy of the R-word index is the highest during the recent economic crisis.

Several interesting conclusions arise from the above presented literature review. First, all of the so far existing versions of media-based economic uncertainty indices are formed and published strictly in highly developed countries. This paper aims to put Croatia "on the map" in that context, and make it the first world emerging economy to have its own version of a media-based economic uncertainty index. Up to this point in time, the analysis of media impact on economic behaviour is almost utterly disregarded by the Croatian academia. One of the rare similar studies which (at least in a wider context) examine the role of media in governing economic processes is done by Sinčić Ćorić and Vuković (2012). Namely, the authors analyse the content of articles in newspapers and web portals, dealing with the topic of lobbying. However, the literature is completely silent on the issue of interrelationships between the media and macroeconomic trends.

Second, the present studies offer quite mixed evidence on the potential usefulness of the R-word index in terms of its leading characteristics. This paper aims to analyse where Croatia stands on the matter: is it possible to employ the media news articles to form a leading indicator of Croatian economic activity? 


\section{Research methodology and data}

Although the cause-and-effect chain between the media, uncertainty, and economic activity is quite obvious, quantifying a media-based economic uncertainty index is a rather difficult task. The next subsection offers a detailed explanation of the methodology used to quantify economic uncertainty via media reports.

\section{Quantifying the R-word index}

It should be noted that the studies cited in the previous section rely on media reports data, gathered from professional media research agencies. This kind of agency does not exist in the majority of emerging countries, including Croatia. Hence the authors were forced to gather a media reports database by themselves. To be specific, the Internet news archives of four highly popular Croatian news portals were examined: Index.hr, 24 sata, Jutarnji list and Večernji list. One might raise the question of the validity of Internet as the source of news coverage data. A strong argument in favour of basing the analysis on Internet data stems from a recent study by the Faculty of Political Science Zagreb and Media Metar (2009). They proved that Croatians perceive Internet as the convincingly most reliable media platform, ranging considerably higher than both the TV and radio. It follows from that the Internet should ultimately lead to unbiased estimates of true economic uncertainty in the system.

The selection of these portals is conditioned by two facts. First, all of them are in the top 10 most visited Croatian web sites overall (Open Society Foundations, 2012). The second reason is that these are the only four web sites for which the authors were able to obtain a coherent article archive without any breaks in the examined time period.

A difficulty of this study is that each of the four analysed news portals has a different starting date of their archives. To be specific, Index.hr data starts from June 2005, 24 sata archives start from August 2007, Jutarnji list dates back to May 2009, while the database gathered from Večernji list starts from November 2011 . Because of that, the R-word index was not formed as the absolute monthly number of recession-related articles, but as the average monthly share of recession news in the total number of news.

The period of analysis in this study is June 2005 - October 2015. In the analysed period, a total of 531,107 news articles were extracted from the four mentioned archives. The entire database was then examined using Structured Query Language (SQL). An advanced search was performed for joint occurrence of several keywords (economic or economy (in Croatian: ekonom, gospodars) and recession, crisis or downfall (in Croatian: recesij, recesiv, kriz, pad). The Croatian language has seven cases, so only the roots of all keywords were searched since there are numerous combinations of all the cases for all examined keywords.

The authors then performed an in-depth analysis of the search results, yielding a final number of 21793 articles dealing with the issue of recent recession.

A quarterly version of the R-word index is also obtained to test the hypothesis $\mathrm{HI}$ (time span of 2005 Q3 - 2015 Q3). Within testing the same hypothesis, real year-onyear (y-o-y) GDP growth rates are also examined (time span of 2005 Q3 - 2015 Q2). The source of GDP data is Eurostat.

Monthly R-word index and confidence indicators from five separate economic sectors are analysed to test the second hypothesis. The period of analysis for this hypothesis is conditioned by the commencement of BCS in Croatia. For the 
consumer surveys, the analysed period is June 2005 - October 2015, while the period for the other four BCS sectors is May 2005 - October 2015. BCS data are gathered from the European Commission.

All variables in this study are seasonally adjusted using the ARIMA X12 method, which is rather standard in time series analysis.

The next subsection provides a brief review of BCS data used in testing the second hypothesis of the paper.

\section{Methodological foundations of Business and Consumer Surveys}

BCS are qualitative surveys conducted with the aim to provide information on a wide range of variables that are useful in monitoring, explaining and forecasting changes in the cyclical developments and in detecting the economic cycle turning points. BCS are continually being conducted monthly in the manufacturing industry, construction, retail trade, services and among consumers. Croatia's BCS are a part of Joint Harmonized EU Programme of BCS from May 2005 (in the consumer sector), and from May 2008 in the other four sectors.

Each BCS variable can be used as a short-term forecasting indicator for the corresponding macroeconomic variable. It is of interest here to track primarily the direction of changes in a particular variable and in its corresponding referent series (e.g. industrial production, private consumption, GDP, etc.). This is important since the BCS data are usually available before the corresponding official statistics are published.

BCS provide data on managers' and consumers' economic assessments and expectations, which are then aggregated and translated into quantitative indicators. The most common way to do that is by using response balances (Čižmešija, Erjavec, Bahovec, 2010)). Response balance is the difference between weighted percentages of positive and negative answers to a particular BCS question. It is calculated for all the questions (variables) in the survey. The next step in the aggregation of survey results is the calculation of composite confidence indicators.

There are a large number of composite indicators derived from BCS. In accordance with the harmonised EU methodology (European Commission, 2016), five indicators are selected: one from the consumer survey and four from the business survey. The Consumer Confidence Indicator (CCl) is a simple average of seasonally adjusted balances of four variables: financial position of households, general economic situation, unemployment expectations (with inverted sign) and saving over the next 12 months. $\mathrm{CCl}$ provides information on consumers' spending and savings intentions, as well as their perception of the prevailing economic conditions, which heavily influence their every-day decisions. The Industrial Confidence Indicator ( $\mathrm{ICl}$ ) is an indicator of business climate in the manufacturing industry. It is calculated as a simple average of seasonally adjusted balances of three variables: order books, production expectations and the stock of finished products (with a negative sign). The Construction Confidence Indicator (BCI) is a composite indicator, which expresses construction managers' expectations and assessments. It is as a simple average of seasonally adjusted balances of two variables: order books and production expectations. A composite indicator derived from the retail trade survey is called the Retail Trade Confidence Indicator (RTCI). It is defined as a simple average of seasonally adjusted balances of present business position, assessment of stock of finished products and business expectations. The Services Confidence Indicator $(\mathrm{SCl})$ is a simple average of seasonally adjusted 
balances of the past business situation, turnover over the past three months and expected demand.

\section{Empirical results and discussion}

The principal contribution of this paper is the publication of Croatian R-word index, which is depicted in Figure 1 in the original form (not seasonally adjusted).

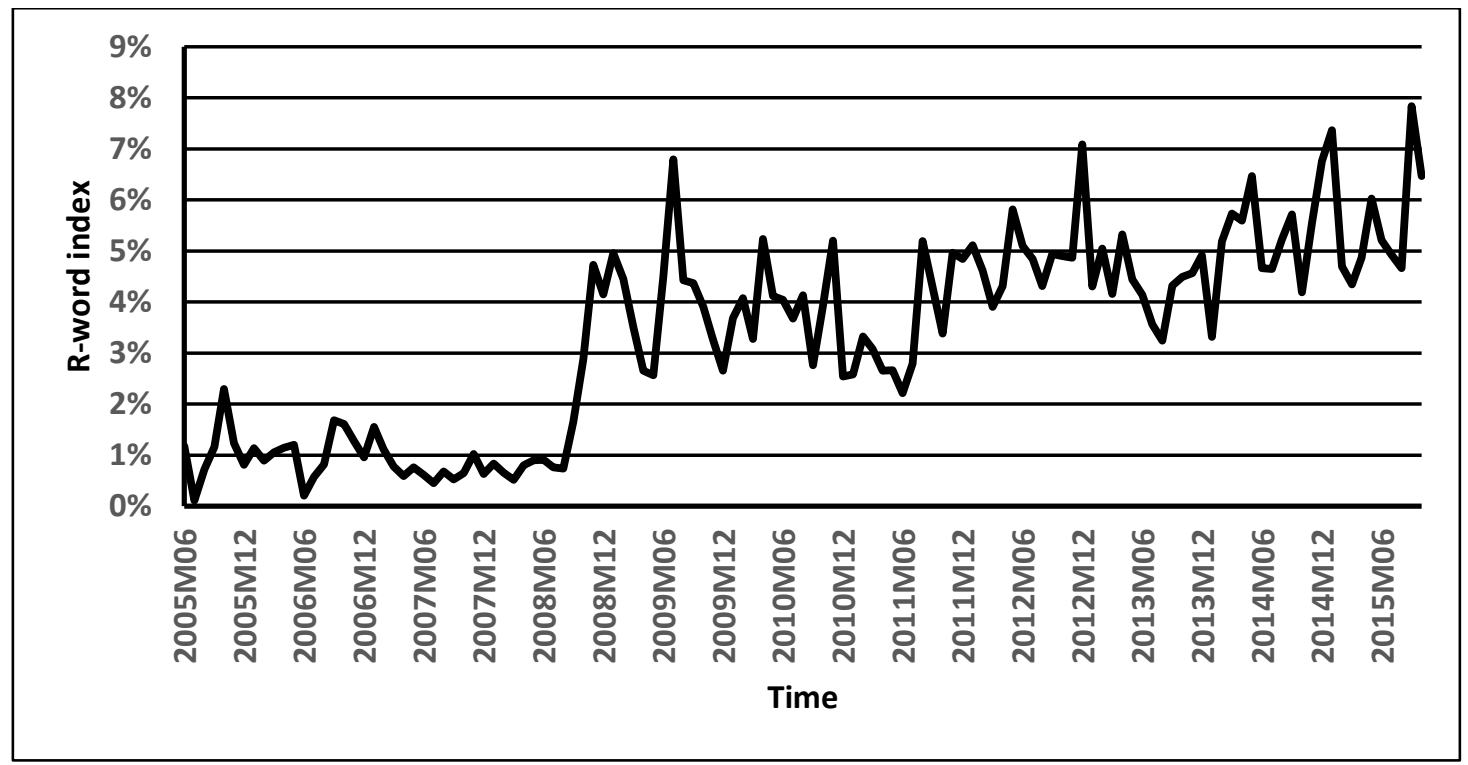

Figure 1 Croatian R-word index

Source: authors' calculation.

One can easily observe that the first three years of the examined period are characterized by extremely low levels of economic uncertainty (i.e. small share of recession-related articles in the news media). This is conditioned by the fact that Croatia witnessed solid economic growth rates in the period of 2000-2007. However, an abrupt jump (structural break) is evident at the dawn of the recent economic crisis. The R-word index more than doubles in August 2008 in comparison to the previous month (an increase from 0.0076 to 0.0165 ). At that point, the news media started to extensively report on the collapse of the real estate market and the potential bankruptcy of several large investment banks in the USA. Since Croatia is a small open economy, it was quite clear that the subsequent cause-and-effect chain will ultimately results in a drastic fall of aggregate demand and push the domestic (Croatian) market into a recession. Although the official confirmation of the recession came from the Croatian Bureau of Statistics in as late as 2009 Q1, the media reports unambiguously reflected the rising uncertainty in the economic system. An informal corroboration of turbulent economic conditions came from the former Croatian Prime Minister (PM) Ivo Sanader. In his famous interview, he admitted that Croatia is "hanging by a thread" (Večernji list, 2008). The next hike of the R-word index is documented in July 2009, with a value of 0.0680 . This finding can largely be attributed to Sanader's resignation as PM. Another important event happened during the same month. Jadranka Kosor took the PM's office and introduced the economic recovery program (manifested through rising value added tax and the introduction of the so-called crisis tax).

Considering the fact that Croatia has recorded the longest negative economic streak in modern European history (Jutarnji list, 2014) (12 consecutive quarters of 
negative GDP growth), it is no surprise that the R-word index has a long-term rising trend ever since the dawn of economic crisis up until 2015. The overall maximum of uncertainty is achieved in October 2015 (R-word index equals 0.0784). This means that as much as $7.84 \%$ of all media articles in that month (dealing with a wide range of topics, from gossips to science) are attributed to contractionary economic trends. One might want to put the hereby given frequency of recession-related articles in a wider context and compare it to the frequencies of articles dealing with other topics. However, to the best of the authors' knowledge, no such analysis has been performed up to this point in time. Elezović (2012) did the only remotely similar study, examining the frequencies of various topics in newspapers cover pages.

A plausible explanation of this extremely high figure stems from the concurrent parliamentary electios. During the campaign, a variety of alternative economic policy prospects were presented to the public by a range of political parties, ranging from neoliberal (pro-market) policies to neo-Marxist and anti-capitalist movements. Hence, an extreme level of economic uncertainty comes as a logical consequence.

In order to question the first hypothesis of the paper, the authors of similar studies employed advanced statistical methods such as vector autoregression models (Doms and Morin, 2004), autoregressive distributed lag models (Iselin and Siliverstovs, 2013), probit regressions (Grossarth-Maticek and Mayr, 2008), etc. However, being an emerging country, Croatia has archive data only for the last 10 years (at most). If one wanted to quantify the relationship between the R-word index and GDP in Croatia, one would have to obtain a quarterly version of the former variable. Following this approach, the present study resulted in only 40 quarterly observations of GDP and the R-word index (2005 Q3-2015 Q2). This limitation has restricted the authors to use rather simple explorative analysis.

Regarding the first hypothesis of the paper, it is crucial to inspect whether the Rword index leads (precedes) GDP, and by what lead time. With that in mind, the two examined variables are graphically presented in Figure 2.

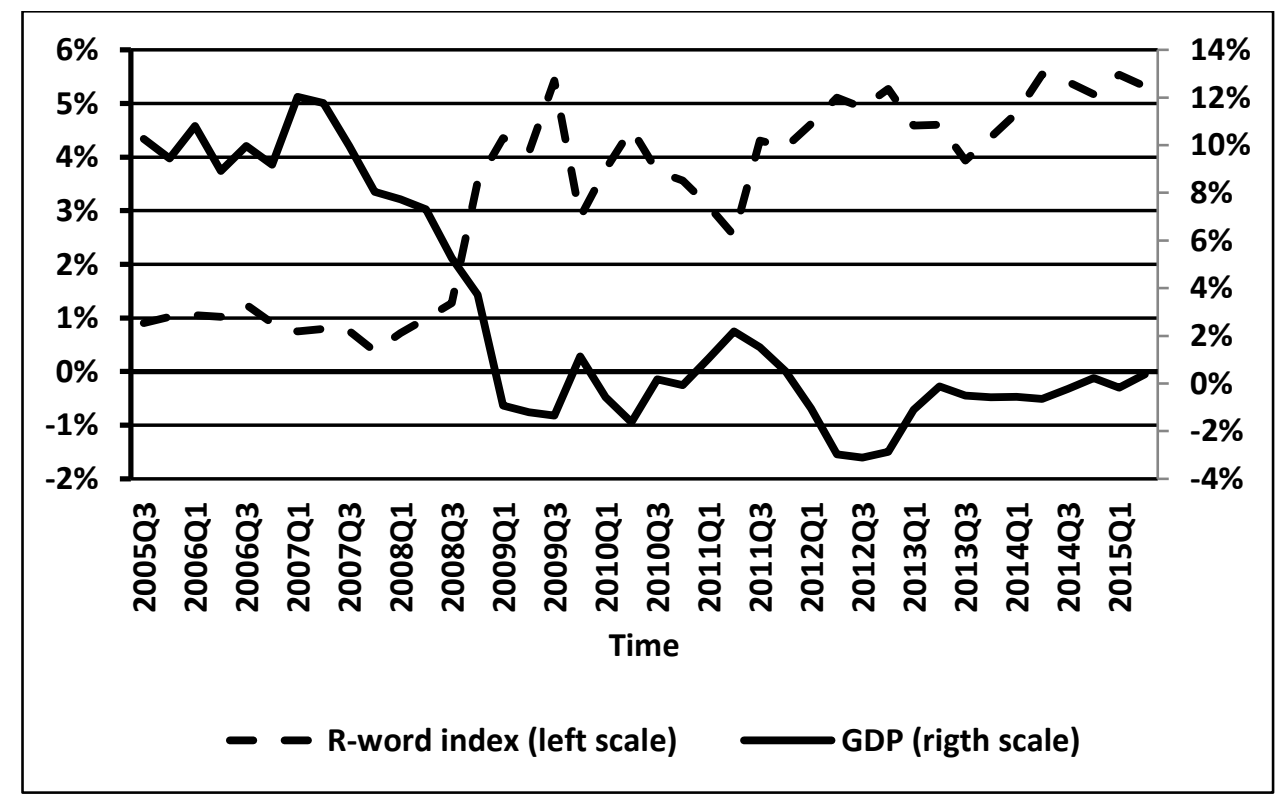

Figure 2 Croatian R-word index (quarterly) and y-o-y GDP growth rates Source: authors' calculation.

It is evident that the two series are strongly negatively correlated. As postulated, an increase of uncertainty in the system (measured by the quarterly R-word index) 
coincides with a decrease in economic activity. The evidence is so strong that the two series almost look like a mirror image of one another. Judging from this figure, one can hardly draw any conclusions about the potential leading characteristics of the R-word index.

Researchers often rely on correlation analysis for various lag lengths in order to question the "true" leading characteristics of a particular indicator with respect to its reference macroeconomic series (e.g. Goldrian, Lindlbaver, Nerb, 2001). The correlation coefficients $(r)$ of GDP and various lags of the R-word index $(h=0, \ldots, 8)$ are calculated and presented in Table 1 in order to resolve that issue.

Table 1 Correlation coefficients between the R-word index and Croatian GDP for various leading times

\begin{tabular}{|c|c|c|c|c|c|c|c|c|c|}
\hline$h$ & 0 & 1 & 2 & 3 & 4 & 5 & 6 & 7 & 8 \\
\hline$r$ & -0.9284 & -0.8888 & -0.8296 & -0.7554 & -0.6596 & -0.6061 & -0.5326 & -0.4600 & -0.4179 \\
\hline
\end{tabular}

Source: authors' calculations.

It is again easily concluded that the quarterly R-word index and GDP growth rates exhibit a strong negative correlation. The highest correlation coefficient (in absolute terms) is obtained for the contemporaneous relationship between the two variables. This inference is also confirmed by Granger causality tests, where no causality is found for the specification with the optimal number of lags being chosen according to the Akaike information criterion.

It can, therefore, be inferred that the R-word index does not have pronounced leading characteristics. However, note that the R-word index can be published at the sole end of each month, while the quarterly GDP statistics are published with a substantial time lag. For example, Eurostat published the GDP figure for 2015 Q2 as late as September 8, 2015. This publication lag of more than two months provides considerable added value for the R-word index, and validates it as a leading indicator of GDP. In essence, this means that the R-word index leads GDP by two months.

Measuring the ability of some leading indicator to forecast another macroeconomic variable is often conducted using the confusion matrix (see e.g. European Commission (2016)). It should be noted that the stated methodology analyses the forecasting of direction of change for a particular variable (not its intensity of change) using leading indicators.

Table 2 shows a confusion matrix (with absolute frequencies) for the quarterly Rword index and Croatian $y-0-y$ GDP growth rates. This way it can be inspected whether the R-word index helps to anticipate the direction of change of GDP in Croatia.

Table 2 Confusion matrix

\begin{tabular}{|l|c|c|c|}
\hline \multirow{2}{*}{ Predicted } & \multicolumn{2}{|c|}{ Realised } & \multirow{2}{*}{ Total } \\
\cline { 2 - 3 } & Rise & Fall & 18 \\
\hline Rise & 9 & 9 & 21 \\
\hline Fall & 5 & 16 & 39 \\
\hline Total & 14 & 25 & \\
\hline
\end{tabular}

Source: authors' calculations.

A cautionary note should be highlighted here: uncertainty and GDP should theoretically be (and indeed are) negatively correlated. Because of that, a fall in uncertainty corresponds to a predicted rise of GDP. In other words, a realised rise of 
y-o-y GDP growth rate is correctly predicted by a fall in the uncertainty index (Rword index) in the current quarter in comparison to the previous one. Predicted and realised changes of $y-0-y$ GDP growth rate are presented in Table 2. The corresponding confusion rate $(C R)$ is calculated according to the expression:

$$
C R=\frac{1}{n}\left(n_{r f}+n_{f r}\right) \text {, }
$$

where $n$ is the number of forecasts (39 in this study), while $n_{f r}$ and $n_{r f}$ are the offdiagonal elements of the confusion matrix. It is straightforward to obtain the value of $C R=0.3590$ from Table 2. This means that a rise/fall of the R-word index indicates (in the period analysed in the study) the wrong direction of change in the GDP growth rate only in about $36 \%$ of cases. On the other hand, in the vast majority of cases (64\%), the R-word index helps to anticipate the changes of GDP movements' direction.

This corroborates the first hypothesis of the paper. However, the R-word index can be used as a strictly short-term leading indicator of Croatian economic activity.

The second hypothesis of the paper is tested using centred 2-years rolling window correlation coefficients (24 monthly observations). This simple, but very illustrative technique, allows the authors to gain insight into the time dynamics of the relationship between the R-word index and individual BCS confidence indicators. In essence, this means that the correlation coefficient at time $t$ is obtained by correlating the observations from time $t-12$ to $t+11$ of both examined series. The purpose of this analysis is to examine whether economic agents react to uncertainty shocks differently in times of recession and prosperity. The rolling window correlation analysis is firstly done for $\mathrm{CCl}$ and the R-word index, as shown in Figure 3.

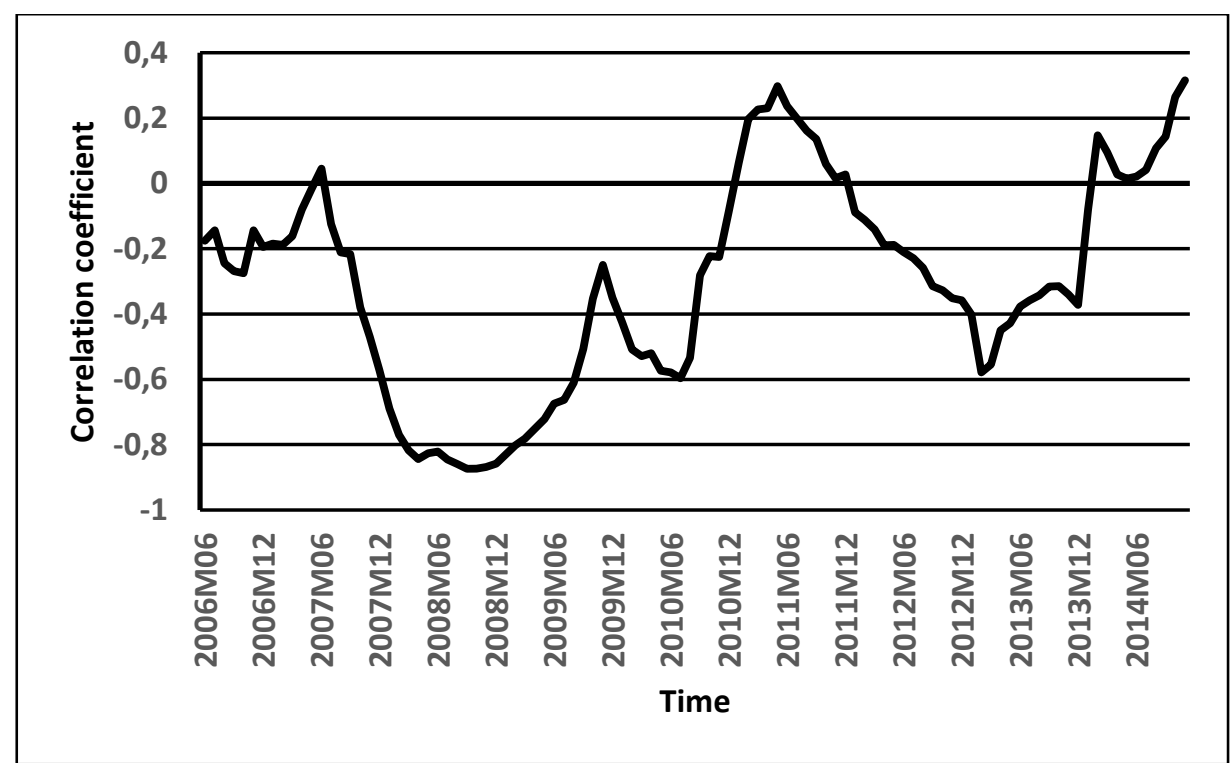

Figure 3 Rolling window correlations of $\mathrm{CCl}$ and the R-word index Source: authors' calculation.

Several inferences can be highlighted here. First, the relationship between the two observed variables is negative throughout almost the entire observed period. Correlation is the strongest (in absolute terms) at the dawn of the Great Recession of 2008 (a value of -0.8737 is documented in September 2008). The correlation substantially moves to the positive territory only within two separate periods. In May 2011 it reaches a maximum value of 0.2975 , which can completely be attributed to 
the documented positive economic growth rates (for the first time after 2008). At that point, the consumers were obviously convinced that the recession came to its end. This was evidently not the case, and the economy shortly sank back to negative growth rates in 2012. The relationship remained rather stable up until 2014, when it was again boosted on the account of economic growth. It is therefore apparent that the correlation cyclically follows GDP movements.

Figure 4 presents the rolling window correlations of $\mathrm{BCl}$ and the R-word index.

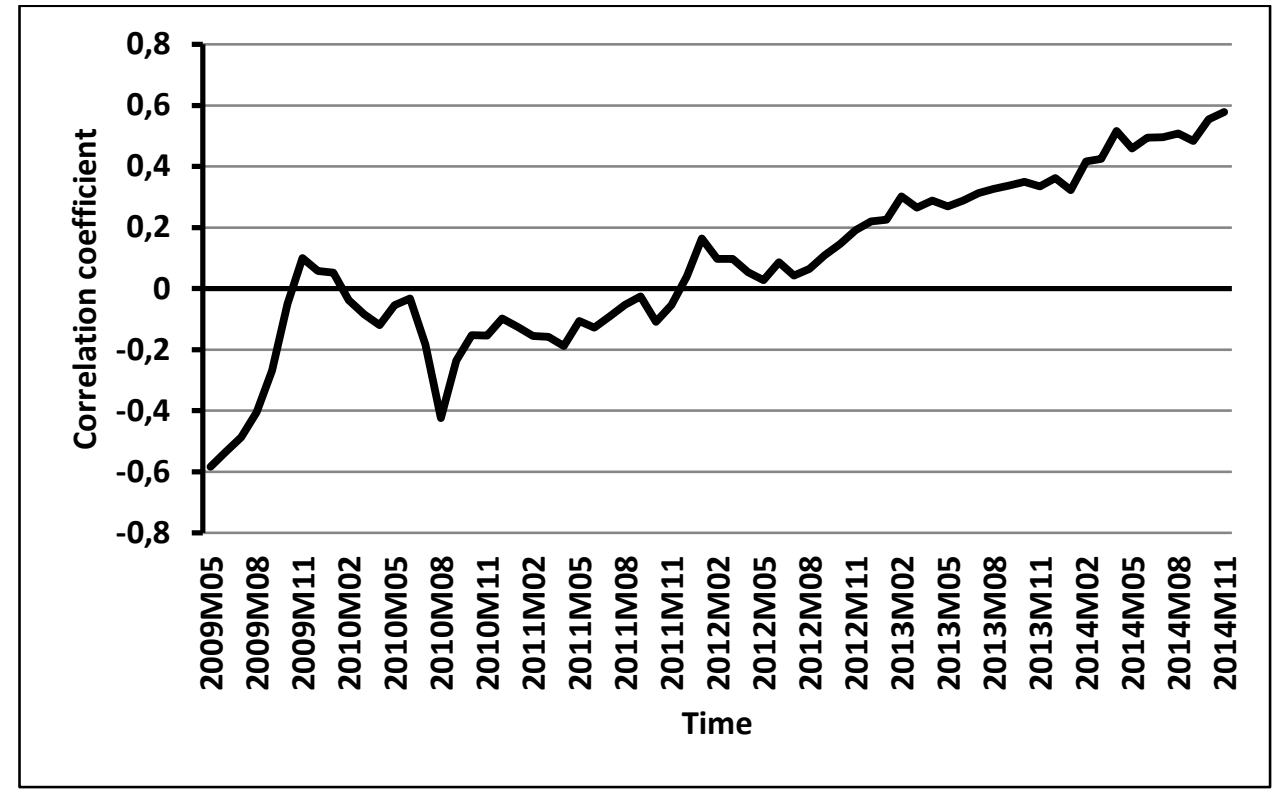

Figure 4 Rolling window correlations of $\mathrm{BCl}$ and the R-word index Source: authors' calculation.

One technical disadvantage is evident here. All Croatian BCS data (except for the consumer sector) are available form as late as May 2008. Since the 2-year centred rolling window correlation entails 12 observations before the centre one, this has shortened the observed period to the starting point of June 2009. Therefore, the analysis is abridged for the observations at the sole dawn of economic crisis. Nevertheless, Figure 4 vividly shows that the correlation of the R-word index and $\mathrm{BCl}$ is the strongest in 2009, within the first recession wave. Afterwards it fluctuates around zero and takes a strong upward trend, defying the official macroeconomic statistics. Despite the fact that the volume of construction works was on the downward trend throughout the examined period (Croatian Bureau of Statistics, 2014), construction sector managers obviously felt that the recession would end before it actually did. Hence, they became more and more optimistic about future prospects of their sector (see Appendix). Since uncertainty also exhibit a long-term upward trend in the examined period, it is obvious that the correlation between the two series has also increased.

Figure 5 shows the rolling window correlation between $\mathrm{ICl}$ and the R-word index. 


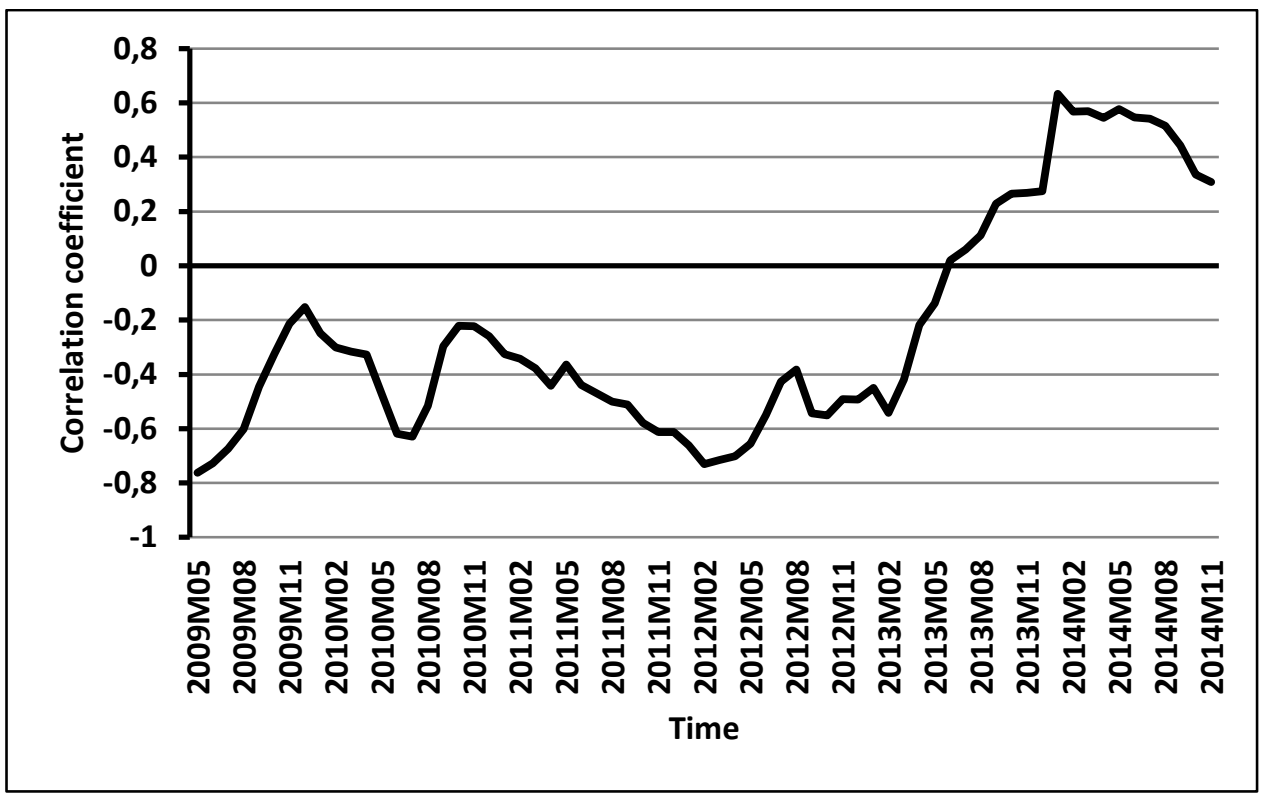

Figure 5 Rolling window correlations of $\mathrm{ICl}$ and the R-word index Source: authors' calculation.

A very similar pattern is also observed in the manufacturing industry sector. The strongest correlation is again found at the beginning of the recent crisis. Afterwards the correlation fluctuates around -0.4 and then takes a strong upward swing. Although the industrial sector recorded negative growth rates in 2013, managers have anticipated a near turning point of the economic cycle. Since uncertainty (measured by the R-word index) also grew in 2013, the final outcome was a rise in the correlation between the two series.

In the same manner, Figures 6 and 7 depict the correlations of the R-word index vs. RTCl and $\mathrm{SCl}$ (respectively).

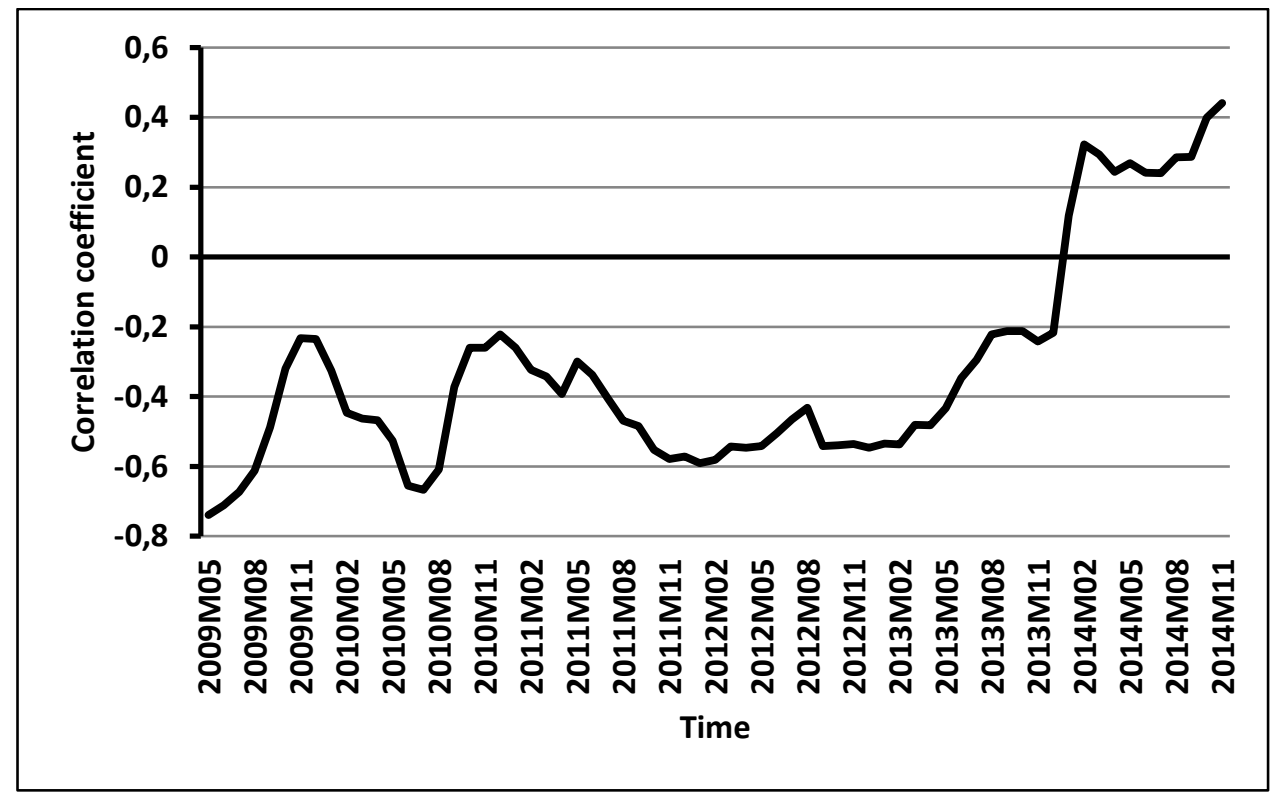

Figure 6 Rolling window correlations of RTCl and the R-word index Source: authors' calculation. 
Exactly the same cyclical developments are vivid in both the retail trade and services sectors. Two variables of interest exhibit the strongest correlation in mid-2009. After the following several years of stagnation, the correlation then takes a strong upswing in 2013.

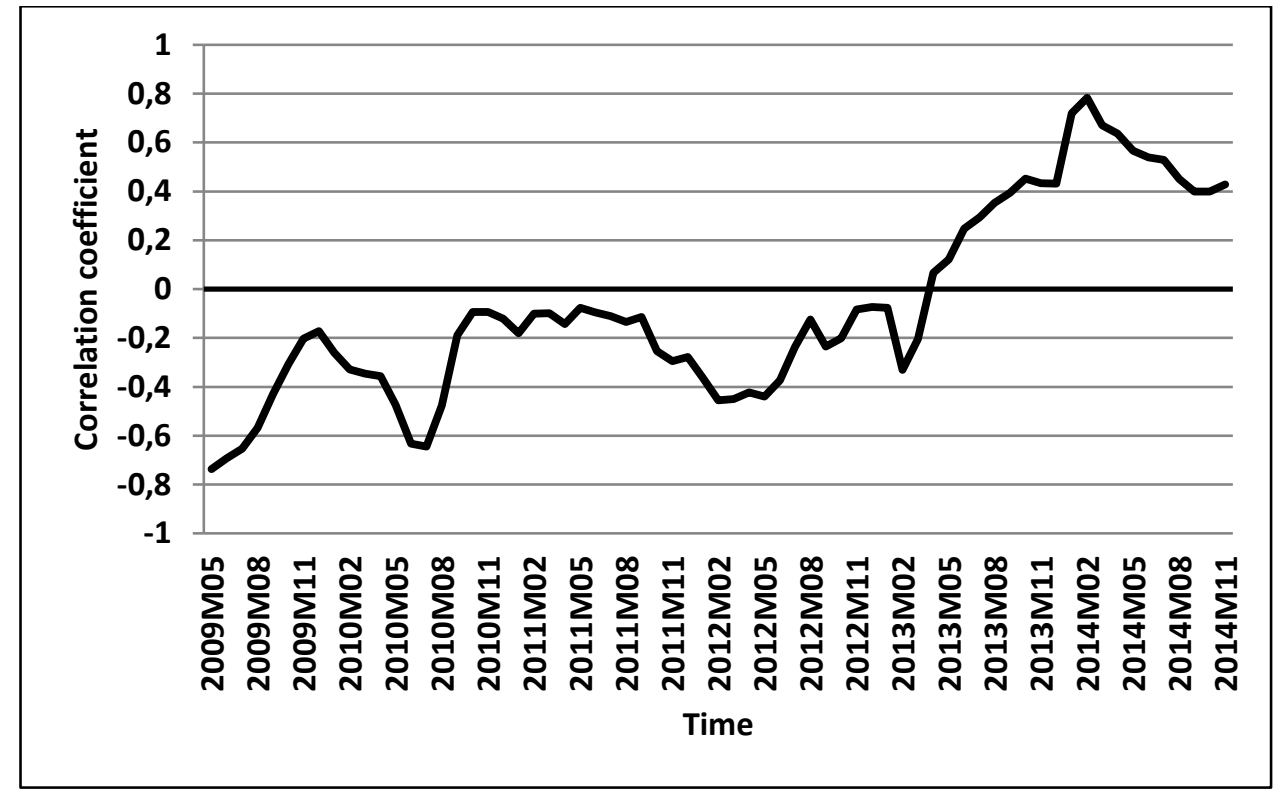

Figure 7 Rolling window correlations of SCl and the R-word index

Source: authors' calculation.

An important conclusion can be uniformly drawn from Figures 3-7. The relationship between economic confidence and the uncertainty level is of different sign and magnitude in different phases of the economic cycle. Very similar results are also obtained by using 3-year centred rolling window correlations. These results are left out here for brevity purposes, but can be obtained from the authors upon request.

Economic agents seem to react to uncertainty shocks the most intensively in the onset of economic crisis. This is completely in line with the work of Garner (1991). He finds that consumer confidence can produce accurate predictions of households' purchases only in the conditions of a sudden (unexpected) economic downfall (such as the Gulf War recession in the USA). This is specifically what happened in Croatia. Economic agents were not fully aware of the possible depth and longevity of the recent crisis in the mid-2008. Although Croatia witnessed a double-dip recession (with the second downfall occurring in 2012-2015), the correlation between economic confidence and uncertainty newer again became as strong as it was in 2008. This time the slump was (at least to some extent) expected and the final effect was not so pronounced. On the contrary, the obtained correlations even became positive for all sectors except the consumers.

At the sole end, an additional robustness check is provided by inspecting the rolling window correlations between GDP $y-0-y$ growth rates and the quarterly version of the R-word index. The obtained results are shown in Figure 8. 


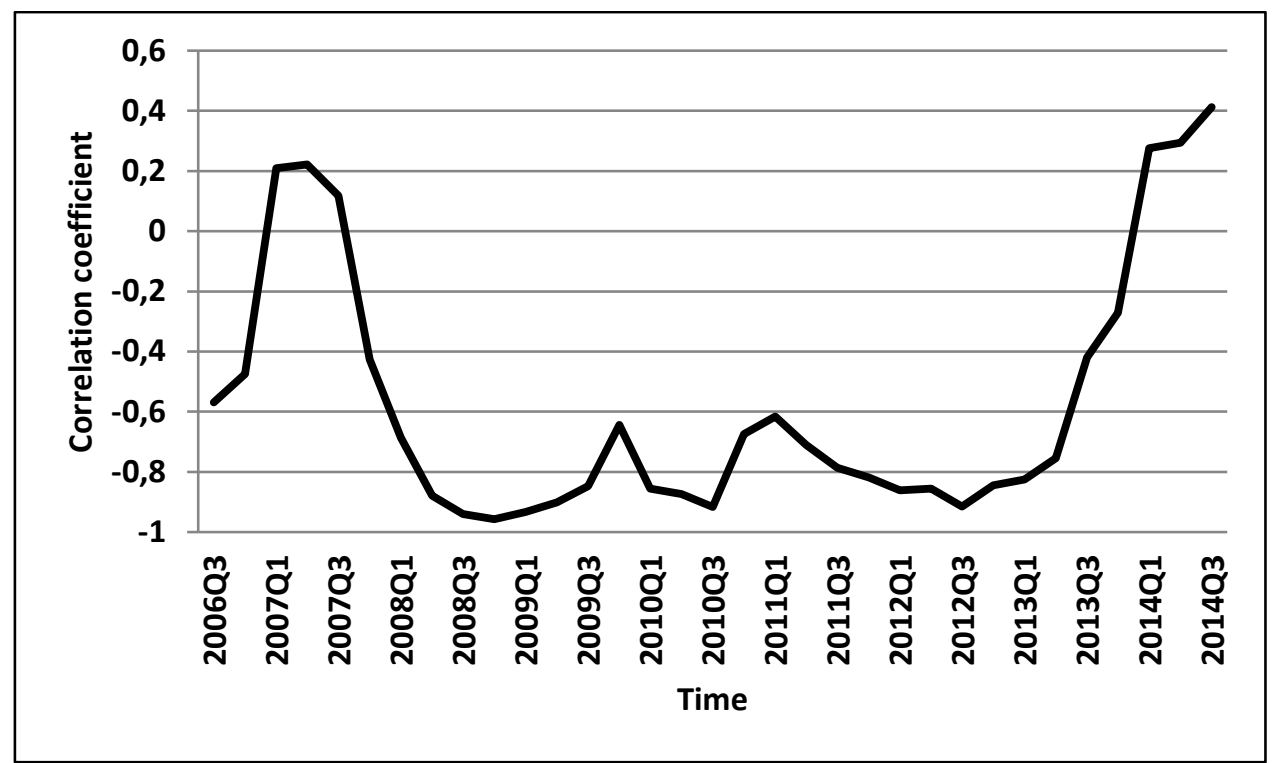

Figure 8 Rolling window correlations of GDP and the quarterly R-word index Source: authors' calculation.

Very similar behaviour is observed once again. The strongest correlation is recorded in mid-2008 (in accordance with Garner's (1991) premise). After several years of mild fluctuations, the correlation skyrockets into positive territory in 2014. This has anticipated the near end of recession: despite the again rising and politically motivated economic uncertainty (parliamentary elections in 2015), the GDP figures start to indicate first signs of recovery. Since the economic sentiment of all five BCS sectors present a similar pattern (Figures 3-7), it is no surprise that the aggregate measure of economic activity also behaves in the same way.

This way the second hypothesis of the paper is also confirmed.

\section{Conclusion}

The largest benefit of this study is that it resulted in a media-based economic uncertainty indicator for the Croatian economy: the R-word index. A coherent database of news media articles is established. The database is set up so that it is automatically refreshed each month. This way, the R-word index can easily be extended by additional monthly observations, and regularly published. The introduction of R-word index significantly augments the Croatian system of coincident and leading macroeconomic indicators, which have until now been almost entirely based on the efforts of researchers from The Institute of Economics, Zagreb (see e.g. Bačić, Vizek (2006) or Rašić Bakarić, Tkalec, Vizek (2015)).

In the context of this paper, the media articles database is searched by keywords related to the economic crisis, but the concept can easily be translated to any other social science field (sociologic, economic, demographic, etc.). Therefore, the contribution of this study is manifold and long-term.

This paper also adds to the literature by examining the (mostly neglected in the literature) time variability of the relationship between uncertainty and economic sentiment. It is firmly corroborated that the correlation between the two variables is the strongest in the sole onset of the economic crisis. This brings the researchers to a very important policy implication. In order to provide a coherent and effective crisis management strategy, the policyholders need to react promptly to the very first signs of recession. A concise public communication strategy needs to be 
articulated, highlighting the economic tools and measures which will be undertaken to fight the crisis, together with an explicit time frame for these steps. This way no additional uncertainty will be generated in the system, economic agents will be fully informed and (to a large extent) able to foresee future macro and microeconomic conditions. In the end, this will ensure more efficient resource allocation, prevent the a priori fear of investing and possibly generate considerable economic gains.

An evident shortcoming of this study is that it does not take into account other popular media (TV and the radio news data). However, that kind of database does not currently exist in Croatia. This disables the authors to widen their analysis to a multi-media framework.

Further research would certainly entail longer time series of R-word index data. This would than enable more rigorous statistical analysis and possibly shed some light on the causal interrelationship among the examined variables.

\section{References}

1. Arčabić, V. (2015). Djelovanje neizvjesnosti na bankarsko tržište u Republici Hrvatskoj. EFZG Working Papers Series, University of Zagreb, Faculty of Economics and Business.

2. Bačić, K., Vizek, M. (2006). CROELI u novome ruhu: treba li nam novi prognostički indeks?. Financijska teorija i praksa, Vol. 30, No. 1, pp. 309-344.

3. Baker, S., Bloom, N., Davis, S .J. (2016). Measuring economic policy uncertainty. Quarterly Journal of Economics, Vol. 131, No. 4, pp. 1593-1636.

4. Bandholz, H., Funke M. (2003). In search of leading indicators of economic activity in Germany. Journal of Forecasting, Vol. 22, No.4, pp. 277-297.

5. Bernanke, B. S. (2012). The Economic Recovery and Economic Policy, Speech at the Economic Club of New York, November 20, 2012. Board of Governors of the Federal Reserve System.

6. Bertola, G., Guiso, L., Pistaferri, L. (2005). Uncertainty and consumer durables adjustment. The Review of Economic Studies, Vol. 72, No. 4, pp. 973-1007.

7. Carroll, C.D. (1992). The Buffer Stock Theory of Saving: Some Macroeconomic Evidence. Brooking Papers on Economic Activity, No. 2, pp. 61-155.

8. Carroll, C. D. (2001). The Epidemiology of Macroeconomic Expectations. NBER Working Paper 8695.

9. Croatian Bureau of Statistics (2014). Statistical Yearbook of the Republic of Croatia, December 2014. Zagreb.

10. Cuñado, J., Pérez de Gracia, F. (2012). Does Media Consumption Make Us Happy? Evidence for Spain. Journal of Media Economics, Vol. 25, No. 1, pp. 8-34.

11. Čižmešija, M., Erjavec, N., Bahovec, V. (2010). EU Business and Consumer Survey Indicators and Croatian Economy. Zagreb International Review of Economics and Business, Vol. 13, No. 2, pp. 15-25.

12. Doms, M., Morin, N. (2004). Consumer Sentiment, the Economy, and the News Media. FRBSF Working Paper 2004-09. Federal Reserve Bank of San Francisco.

13. Eberly, J. (1994). Adjustment of Consumers' Durables Stocks: Evidence from Automobile Purchases. Journal of Political Economy, Vol. 102, No. 3, pp. 403-436.

14. Elezović, A. (2012). O čemu pišu novine? Analiza sadržaja novinskih naslovnica (siječanjlipanj 201 1.). Medijska istraživanja, Vol. 18, No. 1, pp. 61-88.

15. European Commission (2016). European Economy, The Joint Harmonised EU Programme of Business and Consumer Surveys, User Guide updated March 2016. Brussels.

16. Fernández-Villaverde, J., Guerrón-Quintana, P., Rubio-Ramírez, J.F., Uribe, M. (2011). Risk Matters: The Real Effects of Volatility Shocks. American Economic Review, Vol. 101, No. 6, pp. 2530-2561.

17. Garner, A. C. (1991). Forecasting consumer spending: should economists pay attention to consumer confidence surveys? Economic Review, Federal Reserve Bank of Kansas City, Vol. 76, No. 3, pp. 57-71. 
18. Goldrian, G., Lindlbaver,D., Nerb,G. (2001). Evaluation and development of confidence indicators based on harmonised business and consumer surveys, Study of the IFO Institute for Economic Research, European Communities, pp. 21-31.

19. Grossarth-Maticek, J., Mayr, J. (2008). Medienberichte als Konjunkturindikator, Ifo Schnelldienst, No. 61, pp. 17-29.

20. Hypo Vereinsbank (2001). Policy watches economics. 27 April 2001.

21. Iselin, D., Siliverstovs, B. (2013). The R-word index for Switzerland. Applied Economics Letters, Vol. 20, No. 11, pp. 1032-1035.

22. Jutarnji list (2015). Pad BDP-a 'Ovo je još dosad nezabilježeno u Europi. S ovakvim ritmom Hrvatska ide prema bankrotu', 29 August, 2014, http://www.jutarnji.hr/bdp--s-ovakvimritmom-pada-ide-se-prema-bankrotu---lovrincevic/1216319/ [11 November 2015].

23. Kindleberger, C. P., Aliber, R. Z. (2011). Manias, Panics and Crashes: A history of financial crises. Palgrave Macmillan. UK.

24. Knight, F. H. (1921). Risk, Uncertainty, and Profit. Hart, Schaffner \& Marx; Houghton Mifflin Company, Boston.

25. Kose, M. A., Terrones, M. E. (2012). How Does Uncertainty Affect Economic Performance?. World Economic Outlook Box 1.3, pp. 49-53. (Washington: International Monetary Fund, October).

26. Mullainathan, S., Shleifer, A. (2005). The Market for News. American Economic Review, Vol. 95, No. 4, pp. 1031-1053.

27. Open Society Foundations (2012). Mapping Digital Media: Croatia, Country Report.

28. Rabin, M., Thaler, R.H. (2001). Anomalies: Risk aversion. Journal of Economic Perspectives, Vol. 15, No.1, pp. 219-232.

29. Ranyard, R. et al. (2008). Perceptions and expectations of price changes and inflation: A review and conceptual framework. Journal of Economic Psychology, Vol. 29, No. 4, pp. 378-400.

30. Rašić Bakarić I., Tkalec, M., Vizek, M. (2016). Constructing a composite coincident indicator for a post-transition country. Economic research - Ekonomska istraživanja, Vol. 29, No. 1, pp. 434-445.

31. Shah, D. V., Watts, M. D., Domke, D., Fan, D. P., Shah, M. F. (1999). News Coverage, Economic Cues, and the Public's Presidential Preferences, 1984-1996. The Journal of Politics, Vol. 61, No. 4, pp. 914-943.

32. Sinčić Ćorić, D., Vuković, I. (2012). Analiza tiskovnih i internetskih objava o lobiranju u Hrvatskoj. Društvena istraživanja, Vol. 2, No. 116, pp. 545-567.

33. The Economist (2002). The recession index - Words that can harm you -21 November 2002. The Economist.

34. Večernji list (2008). Sanader sindikatima: visimo o niti, u banani smo, 20 November 2008, http://www.vecernji.hr/hrvatska/sanader-sindikatima-visimo-o-niti-u-banani-smo-848279

[10 November 2015].

\section{About the authors}

Mirjana Čižmešija is a Full Professor and Head of the Department of Statistics at the Faculty of Economics and Business at the University of Zagreb. She graduated at the same Faculty in 1990, received her master's degree in 1993 and the PhD in 2001. The field of her interest in scientific research are business statistics and forecasting changes in macroeconomic environment on the bases of business and consumer surveys (BCS). She has published more than 70 scientific papers and has worked on seven books and even more scientific projects. She is a member of International Association of Survey Statisticians (IASS) and of the Centre for International Research on Economic Tendency Survey (CIRET). From 2014 to present, she is the project leader at the "The role of economic sentiment in explaining macroeconomic trends: methodological improvements and new areas of application" project which is funded by the Croatian Science Foundation. The author can be contacted at mcizmesija@efzg.hr. 
Petar Sorić is an Assistant Professor at the Department of Statistics, Faculty of Economics and Business Zagreb (EFZG). His research interests include business and consumer surveys, time series analysis, and macroeconometrics. He obtained a PhD degree in economics at EFZG in 2012, while his international specializations include taking various econometrics courses at the London School of Economics, Cambridge University, University of Crete, etc. Petar Soric is the author of multiple papers in Current Contents-indexed journals. His academic track record has earned several awards, out of which the Croatian National Science Award of in 2013 stands out. Author can be contacted at psoric@efzg.hr.

Ivana Lolić is a Teaching and Research Assistant at the Department of Statistics, Faculty of Economics and Business Zagreb. In 2010 she obtained an MSc degree in Mathematical Statistics and has enrolled into PhD programme in 2013. She is currently finishing her thesis. Her research interests are behavioural economics, time series analysis, and business and consumer surveys. Ivana Lolić has also attended several international econometrics courses at the Cambridge University, Hungarian Central Bank etc. Author can be contacted at ilolic@efzg.hr.

\section{Appendix}

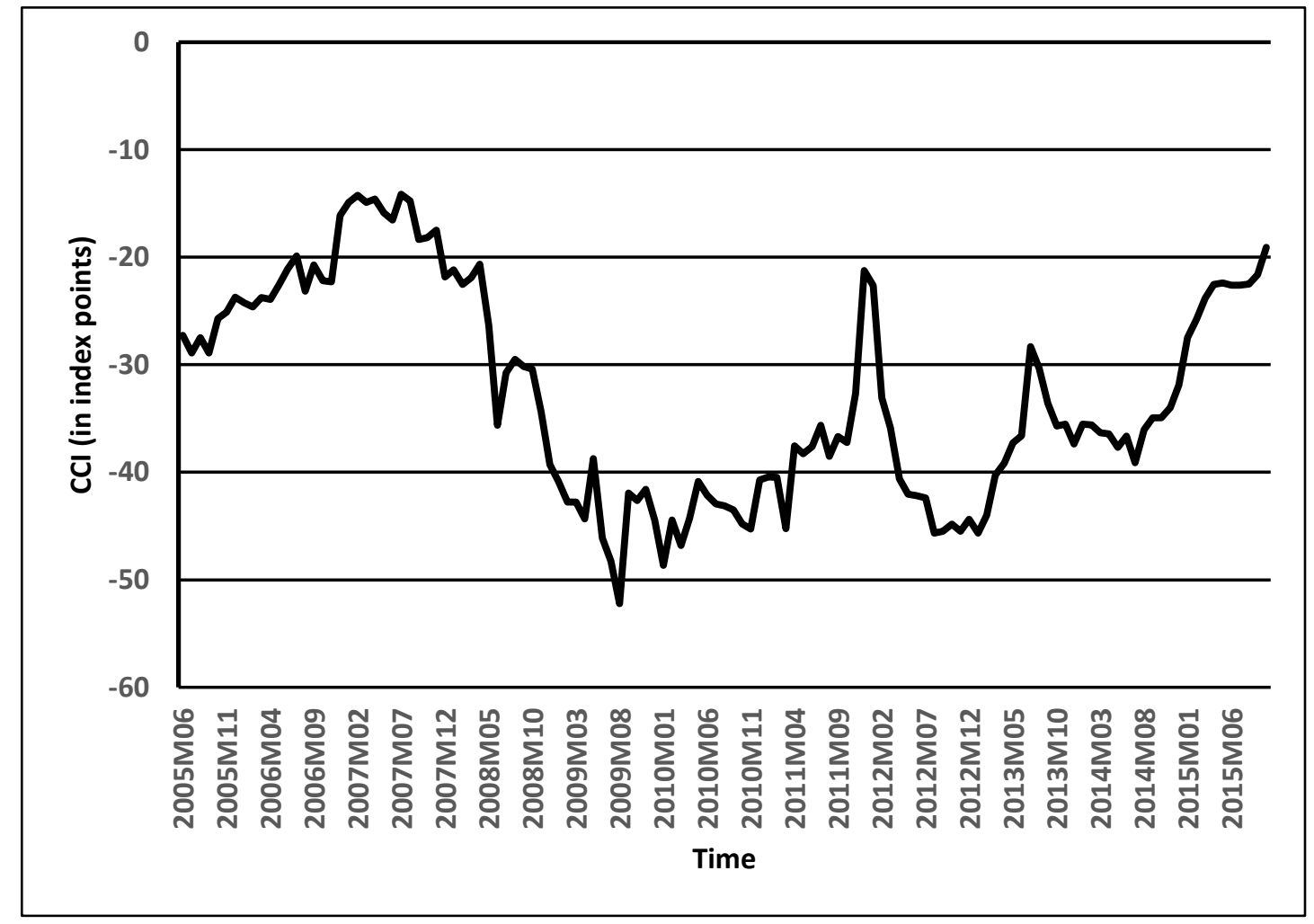

Figure Al Consumer Confidence Indicator

Source: European Commission. 


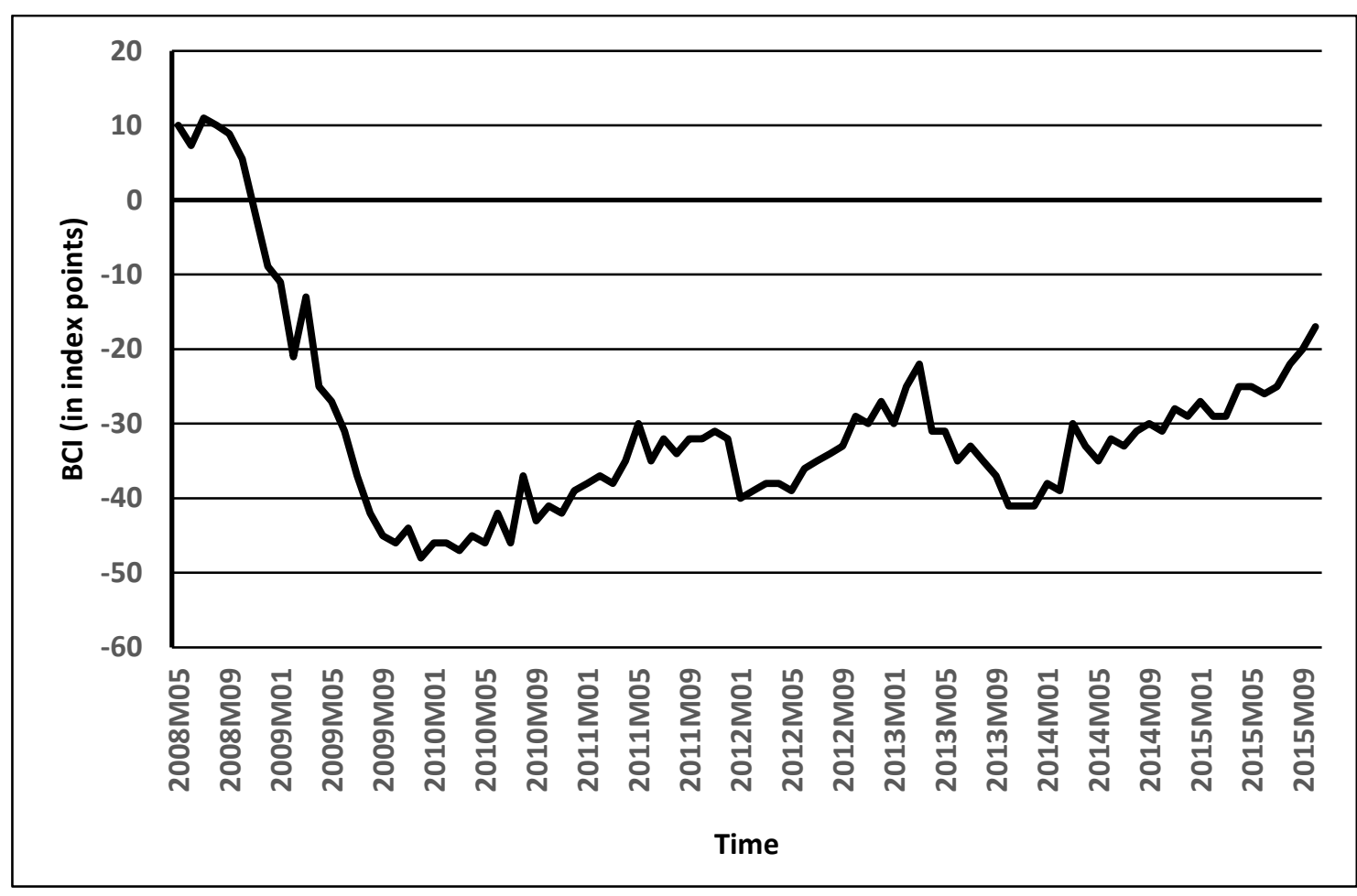

Figure A2 Construction Confidence Indicator

Source: European Commission.

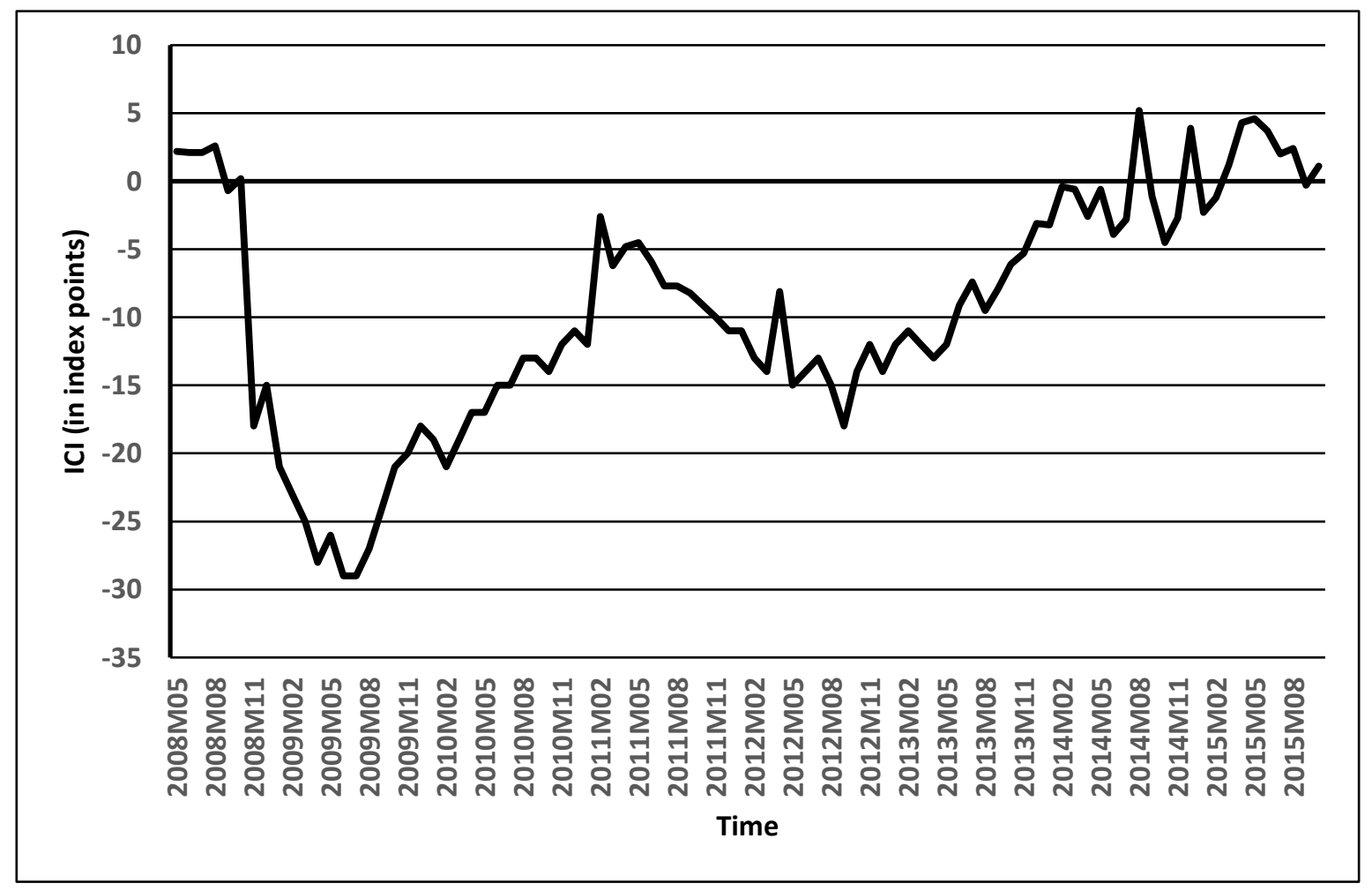

Figure A3 Industry Confidence Indicator

Source: European Commission. 


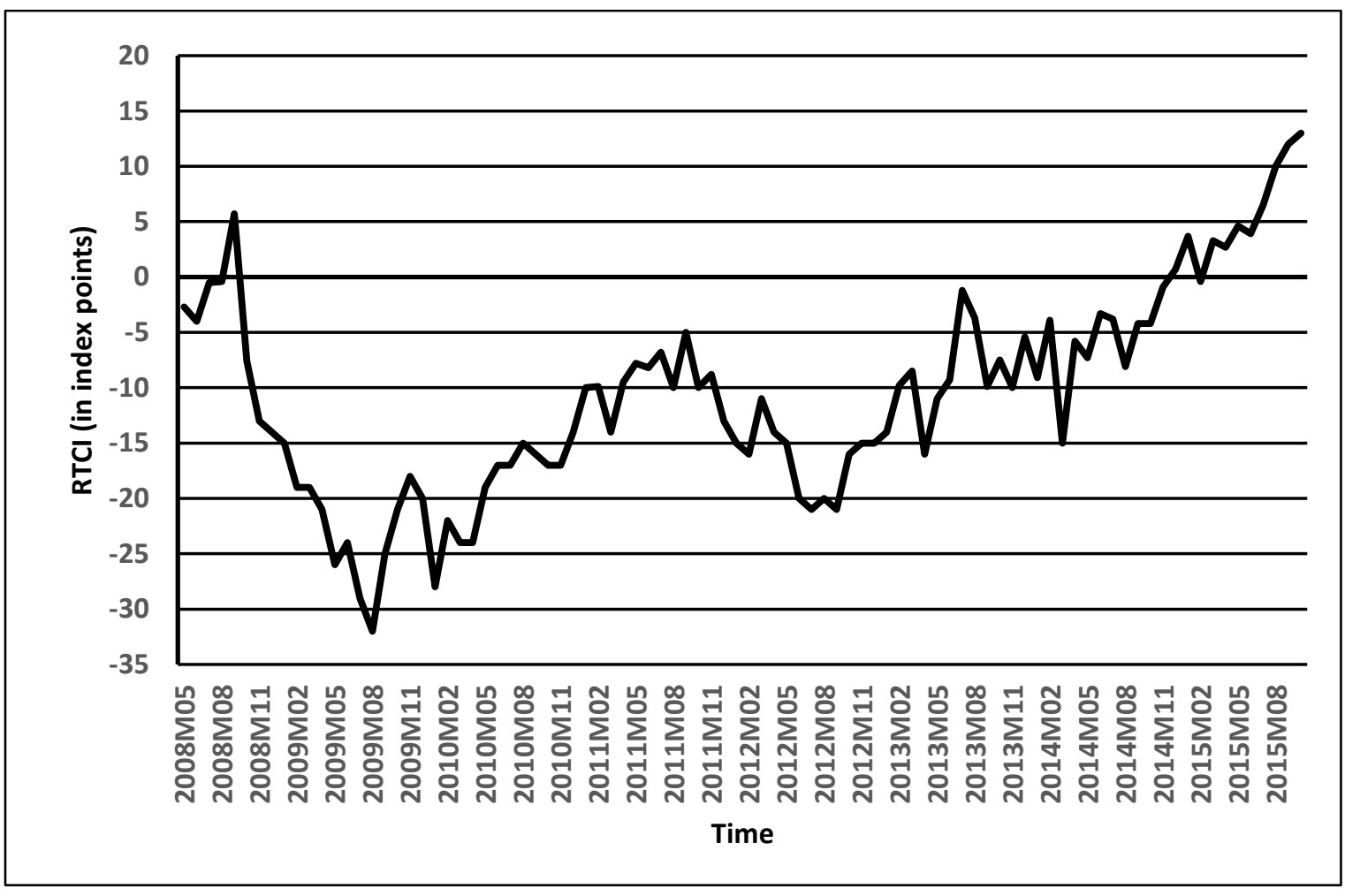

Figure A4 Retail Trade Confidence Indicator

Source: European Commission.

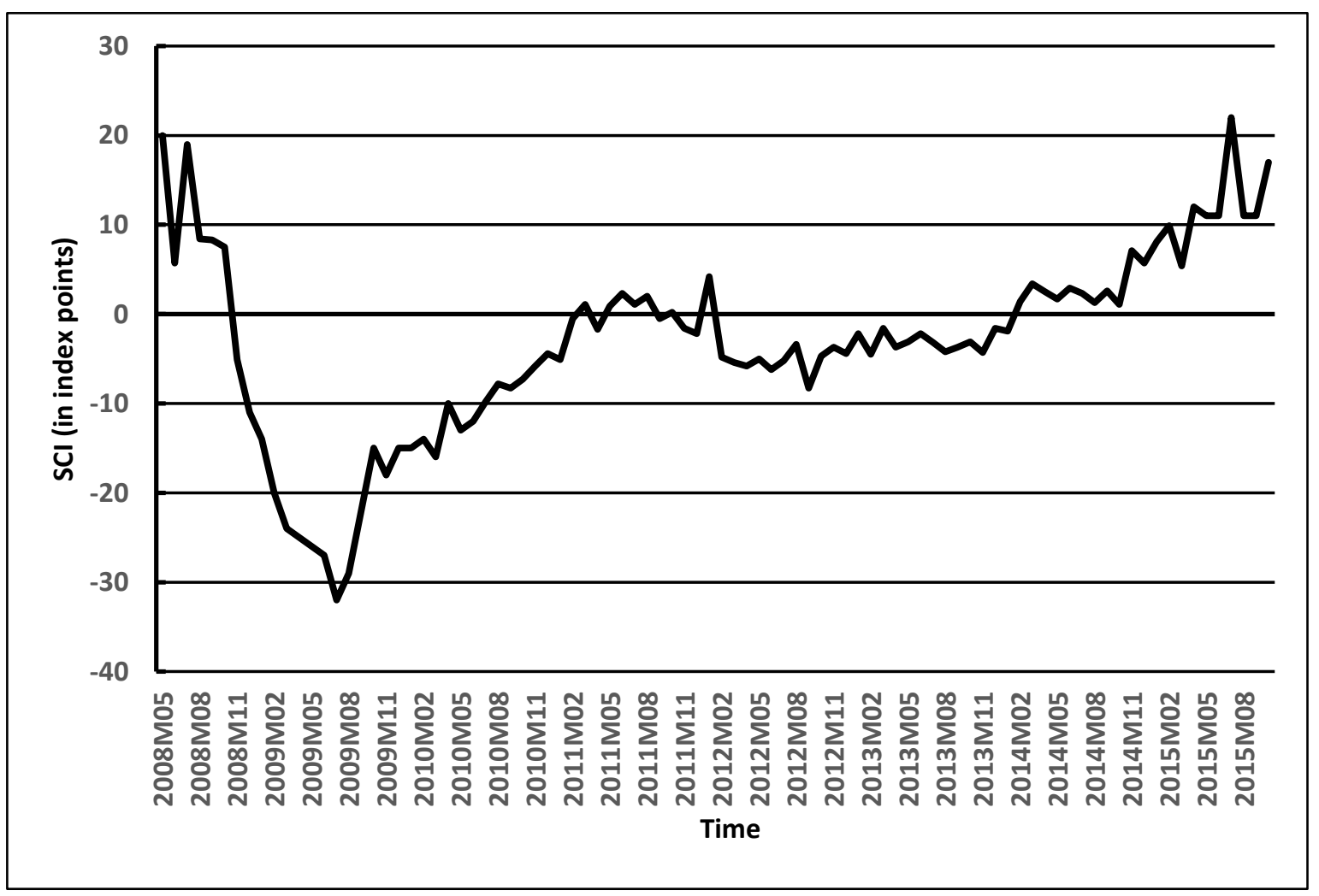

Figure A5 Services Confidence Indicator

Source: European Commission. 